\title{
Pediatricians’ Ideas about Child Development and Education
}

\section{Concepções dos Pediatras acerca da Educação e do Desenvolvimento Infantil}

\author{
Cristina Nunes* \\ Universidade do Algarve, Faro, Portugal
}

\begin{abstract}
In Andalusia (Spain), pediatricians are the main formal counseling source about children's development and education. Unfortunately, there is a limited knowledge about their ideas, practices and skills to guide parents. In this study, through the content analysis of 26 pediatrician interviews, we describe their ideas and goals about anticipatory guidance. We also analyze their perceptions about parental practices and the educative messages given to parents. The results show that pediatrician agenda focus mainly on biomedical issues, such as nutrition, accident prevention and growth monitoring. Child development and education are not priorities and issues like psychomotor development and language are only approached to fill out medical records.

Keywords: Pediatricians’ Ideas; Parental Practices; Child Development; Child Education.

Resumo

Na Andaluzia (Espanha), os pediatras são a principal fonte técnica de aconselhamento sobre o desenvolvimento e a educação infantil. No entanto existe um conhecimento limitado sobre as suas ideias, práticas e habilidades para orientar os pais. Neste estudo, através da análise de conteúdo das entrevistas realizadas a vinte e seis pediatras, descrevem-se os objectivos da agenda pediátrica, as percepções sobre as práticas parentais e as mensagens educativas transmitidas aos pais. Os resultados mostram que a agenda pediátrica é centrada sobretudo nos temas biomédicos, como alimentação, prevenção de acidentes e crescimento. O desenvolvimento e a educação da criança não são prioridades e os temas relacionados com o desenvolvimento psicomotor e linguagem são abordados sobretudo para preencher a história clínica.

Palavras-chave: Concepções; Pediatras; Práticas Parentais; Educação; Desenvolvimento Infantil.
\end{abstract}

The task of parents is to create a safe, coherent and organized world according to norms, rules and values where their children can develop. In this regard, parents need information and orientation to help them make the best decisions and to feel confident about health, development and education-related actions. Parental educational practices do not occur in a void, and they are not automatic reactions to their children's behavior. Indeed, parents think, question, feel and decide (Monteiro \& Castro, 1997; Nunes, 2008).

An emphasis on the cognitive dimension of parental views in the 1980s stimulated research on parental ideas about the nature, development and education of children within the field of developmental psychology. Several studies have shown that parental ideas influence the relationships and educational practices towards their children, which can have significant consequences on children's psychological development (Goodnow \& Collins, 1994; McGillicuddy-DeLisi, 1992; Palacios, Hidalgo, \& Moreno, 2003; Siegel, 1992).

* Address: Universidade do Algarve, Faculdade de Ciências Sociais e Humanas, Departamento de Psicologia, Campus de Gambelas, Faro, Portugal, 8005-139. E-mail: csnunes@ualg.pt
According to Harkness, Super, Keefer, Raghavan and Kipp (1996), parental ideas are a product of the integration of parents' individual experiences and the cultural experiences of the family. Thus, the development of experience within the family and the community, and participation in informal networks of knowledge, contribute to the construction of parental ideas.

Parents' perceptions of “experts”, such as pediatricians, are also important. Several studies have supported the notion that pediatricians are the main technical source for parental advice on the development and education of children (Berkule-Silberman, Dreyer, Huberman, Klass, \& Mendelsohn, 2010; Harkness, Super, \& Keefer, 1992; Harkness et al., 1996; Hidalgo \& Menéndez, 2009; Hidalgo, Menéndez, López, \& Sánchez, 2004; Nunes, 2004; Nunes \& Ayala, 2007; Young, Davis, Schoen, \& Parker, 1998).

Studies by Hidalgo (2003) and Nunes (2008) observed that a significant proportion of mothers attending wellchild program visits in Andalucia (Spain) had doubts regarding the development and health of their children.

The topics that most concern parents of children younger than seven years old are discipline (opposition and aggressive behavior), the use of a pacifier, toilettraining, sleep (waking up at night, refuse to go to sleep 
and nightmares), nutrition (lack of weight gain, gastroesophageal reflux and refusing food) and sexuality (Brayden \& Poole, 1995; Mesibov, Shroeder, \& Wesson, 1993; Nunes, 2008; Young et al., 1998).

In a study that interviewed 200 mothers, Cheng, Savageau, DeWitt, Bigelow and Charney (1996a) observed that most mothers thought that discussions with their pediatricians about biomedical and developmental issues were important even though their children had a low susceptibility to problems. The mothers in the Cheng et al. study believed that doctors were less capable of helping in behavioral matters (discipline and TV watching), safety and family problems (stress, substance-abuse and smoking).

Several studies have suggested that parents would like more information and orientation from pediatricians on subjects related to the education of their children (Olson et al., 2004; Schonwald, Horan, \& Huntington, 2009; Schuster, Duan, Regalado, \& Klein, 2000; Young et al., 1998). In many cases, parents do not seek advice from pediatricians because they feel that the pediatricians are not interested or lack time during visits (Cheng, DeWitt, Savageau, \& O’Connor, 1999).

In turn, pediatricians find that providing advice to parents about the education of their children is difficult for two reasons. First, when parents do not ask questions, pediatricians believe it is due to lack of interest (Cheng et al., 1996a; Cheng, Savageau, DeWitt, Bigelow, \& Charney, 1996b). Secondly, pediatricians themselves do not always have enough information about child development and education (Levetown \& Committee on Bioethics, 2008; MacPhee, 1984; Wissow, Larson, Anderson, \& Hadjiisky, 2005).

In Andalucia, the Well-Child Program is the institutional reference for counseling for pediatricians (Dirección General de Atención Primaria y Promoción de la Salud, 1990). This program has two main components: one concerns secondary prevention and focuses on early detection and treatment of diseases and developmental disorders, and the other is devoted to health promotion and education. The latter component also includes advice seeking to stimulate development and promote healthy habits.

Although the basic training of pediatricians focuses almost exclusively on the diagnosis and treatment of diseases (American Academy of Pediatrics, 1993; Crespo, 1999; Levetown \& Committee on Bioethics, 2008), understanding pediatricians' ideas on the development and education of children as well as their perspectives on the role that these matters play within the Well-Child Program, mentioned above, would be very interesting.

\section{Aims}

The present study was designed to understand the aims and priorities of the pediatricians involved in the "wellchild program", the advice that they give mothers and their perception on parental ideas and practices.

\section{Methods}

\section{Participants}

The present study included 26 pediatricians who participated in the Well-Child Program in healthcare centers in the Seville Province (Spain). Selection was based on accessibility, and all contacted professionals agreed to be interviewed.

The average age of the participants was 42.2 years old $(S D=8.05)$, and the sample included 10 males and 16 females. The average number of years of professional experience was 13 years, and the range was 4-32 years.

\section{Instruments}

We designed a questionnaire that consisted of 27 questions, and it was administered in an interview format. Questions were formulated according to the intervention areas of the pediatricians as defined in the Well-child program: nutrition, sleep, general care, psychomotor development, language, prevention of accidents and diseases (Dirección General de Atención Primaria y Promoción de la Salud, 1990). Before deciding on the final format of the questionnaire, the questionnaire was subjected to a pretesting phase that included five pediatricians who were not included in the study.

\section{Procedures}

The interviews were audio recorded and fully transcribed. In addition, the answers of the pediatricians were codified using content analysis methods (Krippendorff, 1980; Maroy, 1997). The analysis of the answers consisted of the following stages: (a) preliminary reading and listing enunciates, (b) selection and definition of classification units, (c) categorization, (d) quantification, (e) description and (f) interpretation.

We established content units, which were fragments that expressed the same theme or idea, and used a thematic criterion to divide the content units. Importantly, the size of the units varied together with the extension of discourse on a given idea or theme. Thus, in some cases, content units comprised only one word, whereas other cases included several sentences that referred to one theme.

Categorization stages involved the selection of a precise, distinct and representative name for each category. We used exhaustiveness, homogeneity, coherence, objectivization and productivity as criteria. We adopted an "open/inductive" model that included the following phases: (1) Grouping together of units in preliminary categories; (2) Identification of internal subdivisions in subcategories; (3) Analysis of the pertinence of each category and subcategory regarding the included enunciates; (4) Reduction of categories and subcategories by eliminating the redundant ones; (5) Definitive identification and definition of categories; (6) Construction of a codification grid; (7) Final classification of all enunciates within the codification grid. 
For questions about the aims and priorities of the program and topics to be approached with mothers, we used the categories defined in Table 1. Thus, the general field of intervention goals was described in an order from the goals that were more closely related with the biomedical approach to the goals that were more closely related with the psychosocial approach. The "parentscentered" category was created because of the need to highlight communication and participation during medical visits, as well as the perceived role of the pediatrician. "Norms" represented a separate category.

Table 1

\section{Definition of General Categories}

\begin{tabular}{ll} 
Secondary prevention \\
\cline { 1 - 2 }
\end{tabular}

Norms
Intervention aimed at the early detection of states of disordered health and the reduction of consequent damage

Intervention aimed at avoiding the appearance of disease

Actions unrelated to a given disease. It alludes to actions that allow for increased physical and human development of individuals or groups.

Intervention aimed at assessing, orienting or promoting child development

Intervention aimed at assessing, orienting or improving parental educational strategies and actions

Actions aiming at assessing, potentiating or improving the emotional links between the members of a family

Using parents as a source of information to evaluate the health state of their children. Answering their doubts and concerns as to their children's health or emotional state

Application of official norms. Motive of action is seen as agreeing with the norm

\section{Results}

Figure 1 shows the aims and priorities that were reported by the pediatricians. Notably, health promotion and secondary prevention were the most important issues for the pediatricians.
An analysis of the educational messages that the pediatricians reported conveying to mothers (Figure 2) demonstrated that more than half of the pediatricians did not provide advice on subjects such as father-child relationships, psychomotor stimulation, socialization or language.

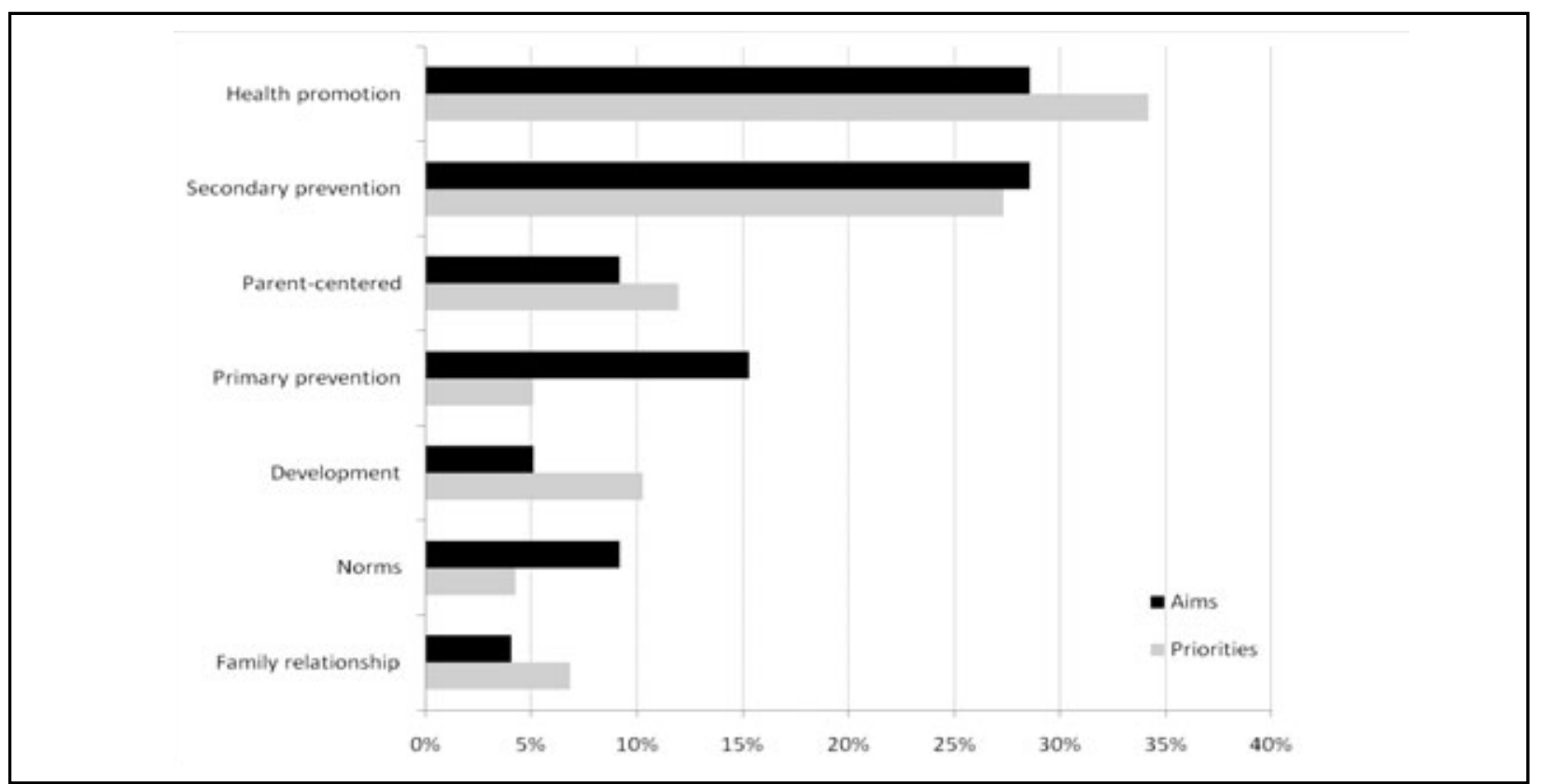

Figure 1. Aims and priorities of pediatricians. 


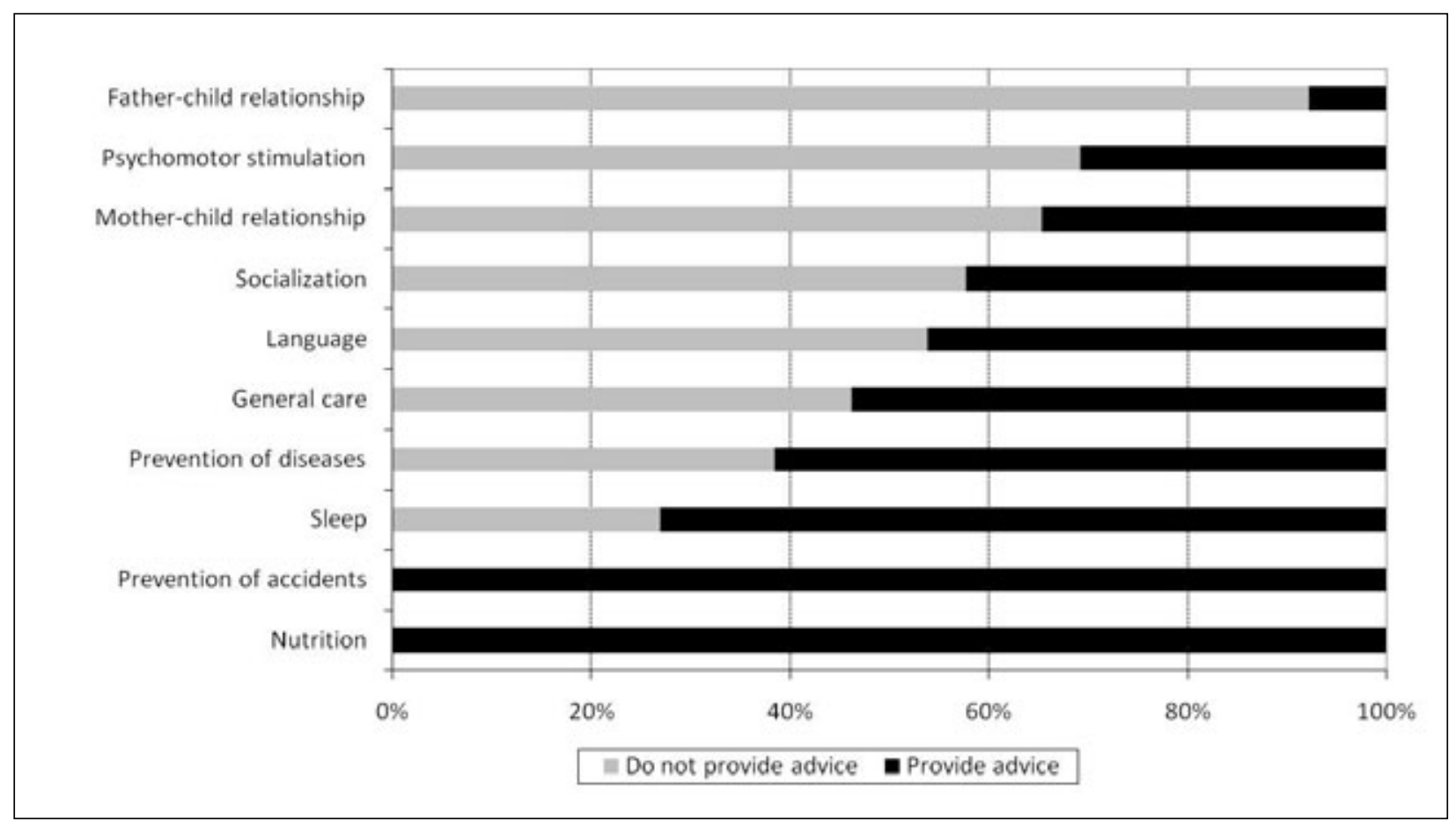

Figure 2. Percentage of pediatricians who provide advice on a given theme.

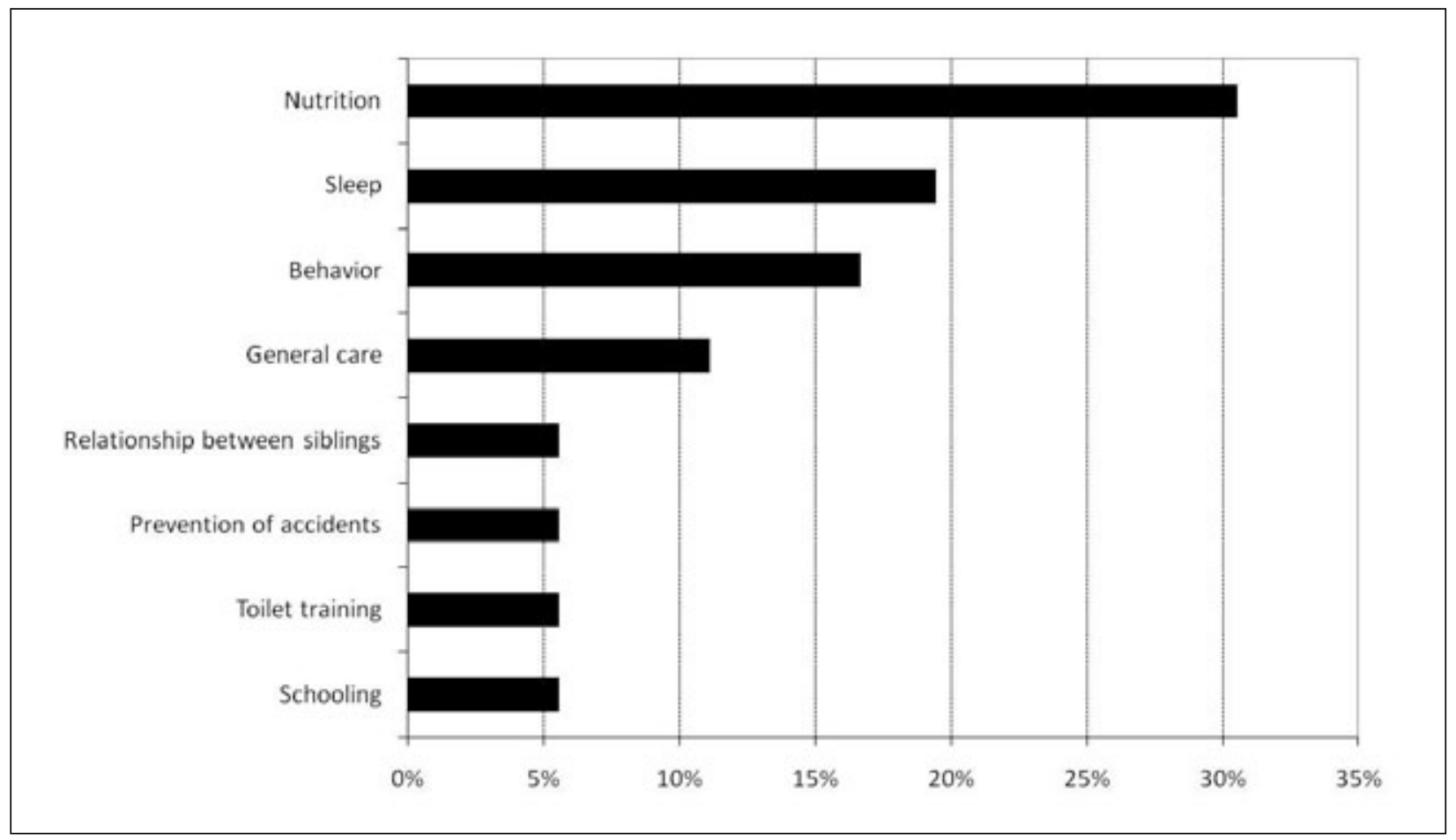

Figure 3. Themes about which mothers most commonly seek advice (according to pediatricians).

The views of the pediatricians about the advice asked by mothers (Figure 3 ) and the mothers' doubts (Figure 4) shows that the agenda of the pediatricians is focused on biomedical topics, such as nutrition, prevention of disease and growth. Psychomotor development, language and education are not commonly mentioned.

The results of the present study suggest that, according to pediatricians, mothers with children younger than six months tended to ask the most questions and seek the most advice from their pediatricians (Figure 5). 


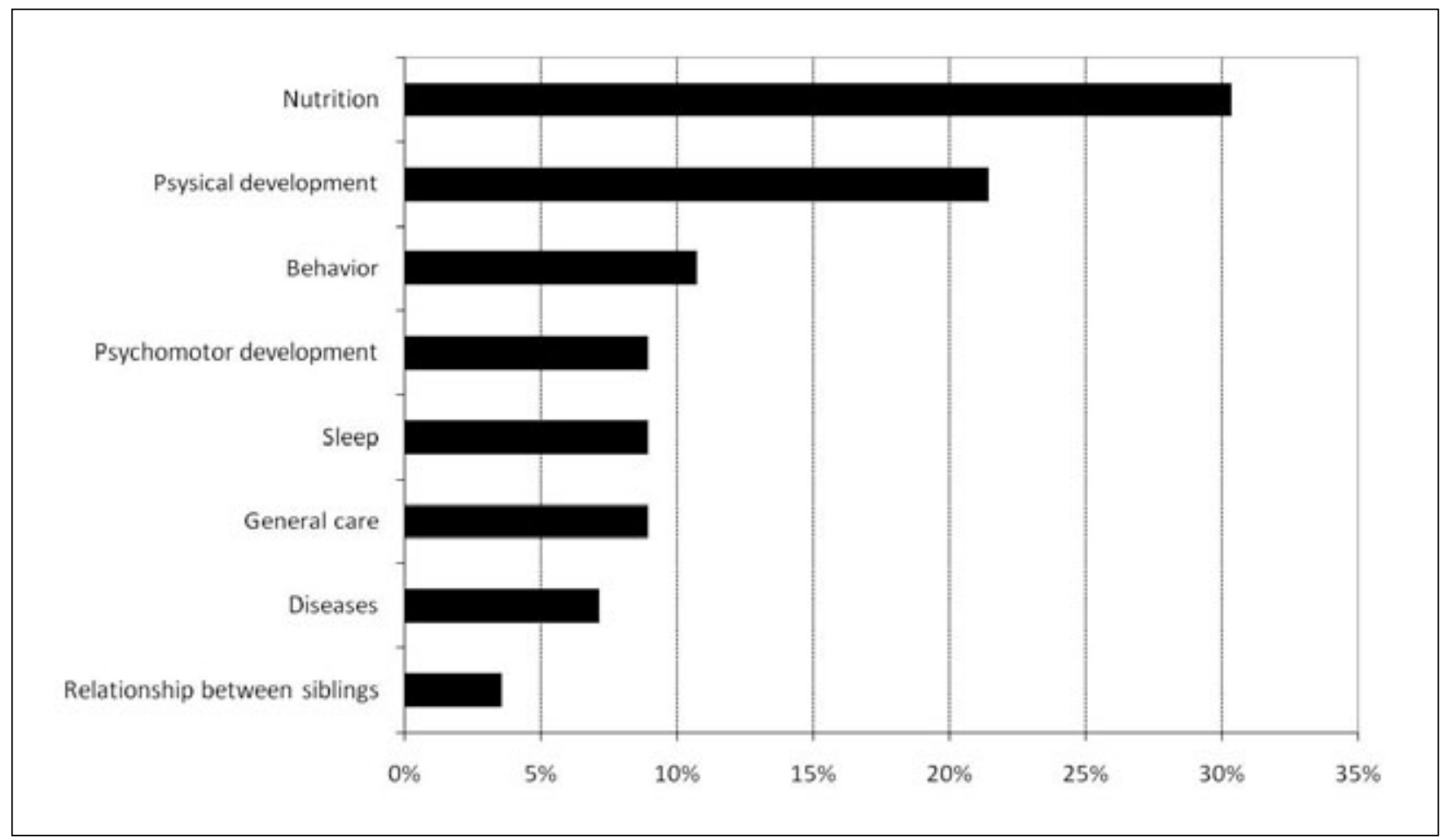

Figure 4. Doubts and concerns of mothers according to pediatricians.

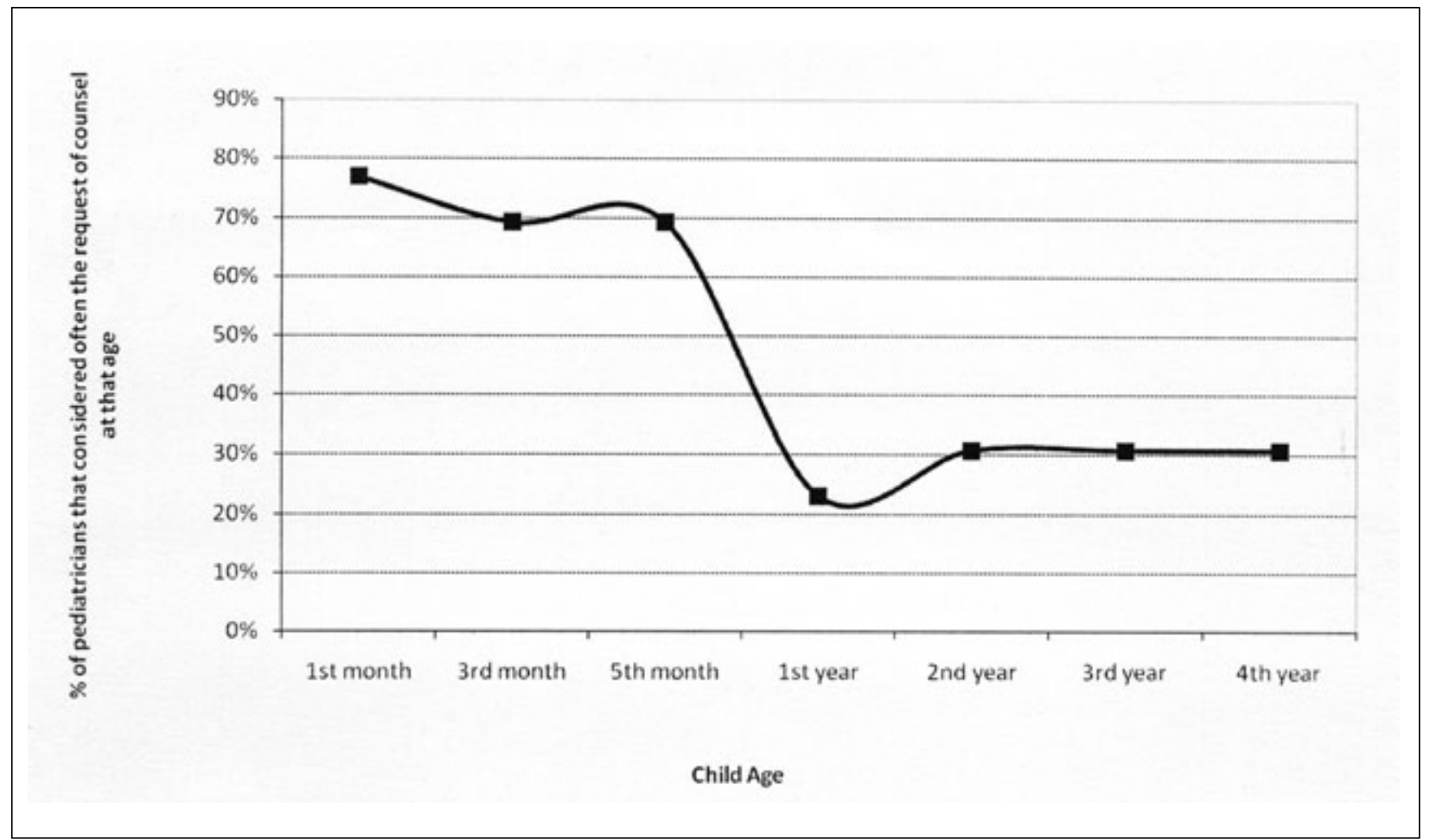

Figure 5. Age of children when mothers ask more advice (according to pediatricians).

The pediatricians held polarized opinions as to the educational ideas and practices of mothers (43\% maintained that children are poorly educated by mothers, whereas $36 \%$ rated the educational ideas and practices of mothers as good). This polarity in opinion would be expected in the general population, but we did not expect to find this result among a population of pediatricians who share a common body of knowledge. 
Figure 6 lists the number of different types of advice reported by the pediatricians and the total number of instances that each piece of advice was mentioned. Both values define one point per topic. Discontinuous line A defines a situation of inter-peer aggregation or maximal concordance. In this hypothetical situation, each pediatrician in the sample $(n=26)$ gives the same advice as his or her colleagues. Thus, if there was only one type of advice, there would be twenty-six mentions. If there were two types of advice, there would be fifty-two mentions, and the same pattern would continue.

Discontinuous line B defines the opposite situation, which we call maximal dispersion. In this situation, no pediatrician gives the same advice as any of the others. Thus, the number of mentions equals the number of different types of advice.

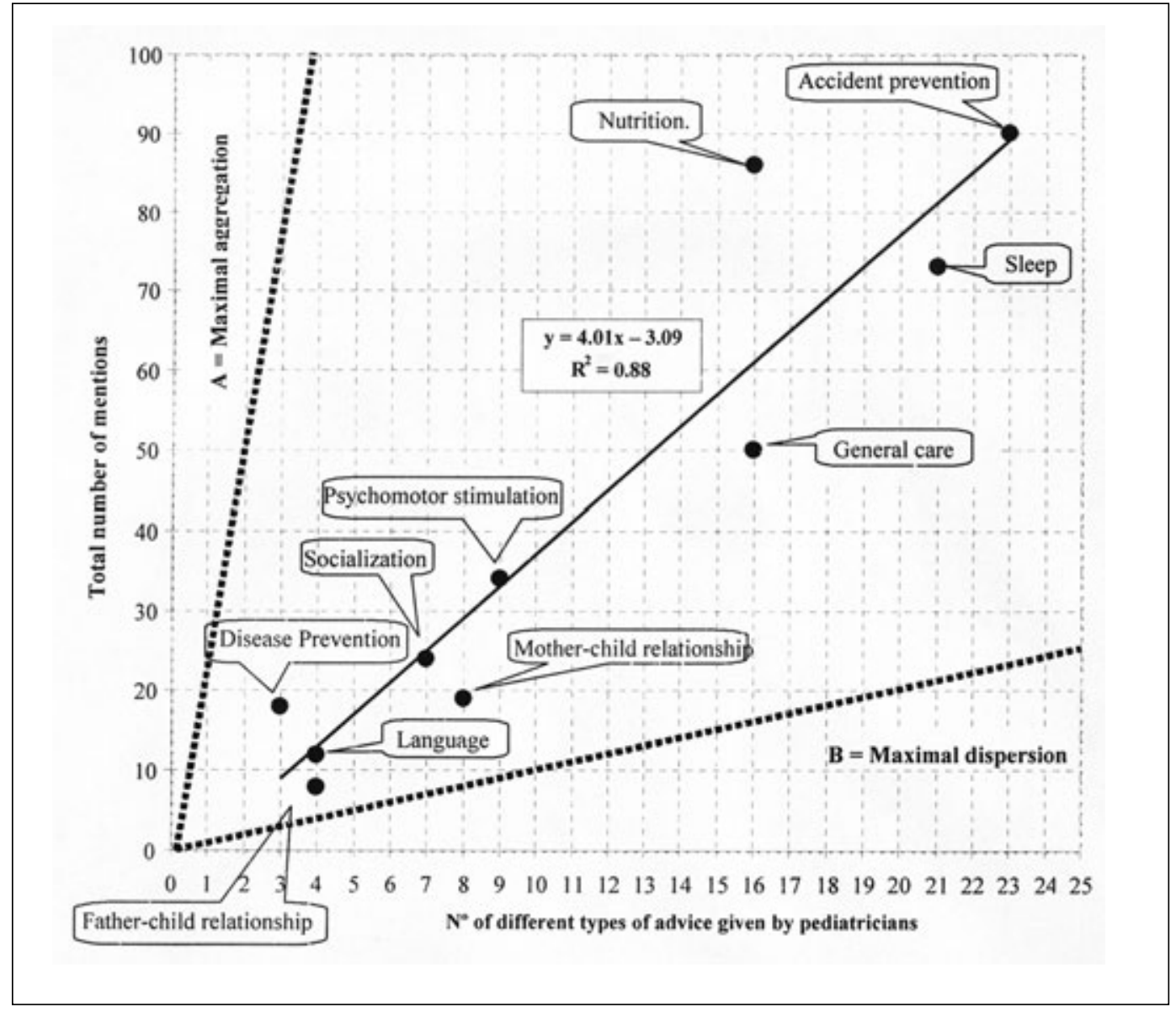

Figure 6. Number of mentions and different types of advice given by pediatricians.

We expected that a professional group making statements on the core contents of its shared knowledge would tend to follow closer to aggregation line A than to dispersion line $\mathrm{B}$.

The central line is the regression line, which expresses the adjacent equation and is adjusted to the data $\left(r^{2}=.88\right)$. Themes above the line exhibit more aggregation, whereas the themes below the line exhibit more dispersion than the average.

The importance that the pediatricians attributed to each theme was directly manifested by both the number of different types of advice (more towards the right side) and the total number of mentions (more towards the upper side). The upper half of the figure contains the themes that were rated as more important: [i.e., nutrition (high aggregation), prevention of accidents (average aggregation) and sleep (low aggregation)], and the lower half of the figure contains the themes about which the pediatricians reported providing less advice [i.e., prevention of diseases (high aggregation), psychomotor stimulation, language and socialization (average aggregation) and the relationship between the parents and the children (low aggregation)]. General care was in the middle and exhibited high dispersion.

\section{Discussion}

The present study found that the aims and priorities of the pediatricians were anchored in the basic issues of health promotion and secondary prevention. Themes rela- 
ted with child development were not a priority, and psychomotor development and language were only mentioned from the perspective of the detection of disorders.

We also observed a high degree of concordance between the aims and the priorities of the pediatricians and the themes that were addressed during visits. Mothers are rarely asked to express their doubts, and opinions and issues related to education and family relationships are rarely raised. Nevertheless, most of the pediatricians negatively evaluated how mothers educated their children.

The extreme variability of the answers given by the pediatricians when we asked them how often mothers sought their advice about education and the type of advice that they gave the mothers might be due to variability in the population of the mothers. A more likely explanation, however, is that the differences arose from the different professional styles of the pediatricians. These hypotheses need to be tested in future studies to have a better understanding of variability among pediatricians.

We observed patterns between the ages of the children, the themes that most commonly caused mothers to seek advice, the themes causing doubts and the priorities that pediatricians attributed to the program. In the present study, the most important themes were nutrition, physical development and sleep. Interestingly, psychological development was less of a concern. Importantly, the results of the present study agreed with the literature (Galuska et al., 2002; Manning, Ariza, Massimino, \& Binns, 2009; Schuster et al., 2000; Young et al., 1998).

Behavior was never mentioned as the initial reason that mothers sought advice from the pediatricians. In addition, opposition behavior, aggressiveness, child sexuality and nightmares were never perceived by pediatricians as reasons for doubts; however, other studies have shown that these factors are a common cause of parental concern (Brayden \& Poole, 1995; Mesibov et al., 1993; Nunes, 2008; Olson et al., 2004; Schuster et al., 2000; Young et al., 1998).

When addressed as a whole, the present data are compatible with the results of several studies showing that maternal concerns are a highly significant source of information that is clearly underestimated by pediatricians (Cheng et al., 1996a, 1996b; Glascoe, 1997; Glascoe \& Dworkin, 1995; Hart, Kelleher, Drotar, \& Scholle, 2007). The role of mothers as an information source regarding the diagnosis of children is important in almost all kinds of health problems, even though there is some variability in the information provided by the parents. When the topic is developmental, language, behavior or learning disorders, however, the diagnostic skills of pediatricians critically depend on their ability to identify the doubts and concerns of mothers.

When we investigated the recommendations that the pediatricians made in detail, we could clearly see the real agenda of the pediatricians. Indeed, there were only two subjects (i.e., nutrition and prevention of accidents) that all pediatricians reported providing advice about. More than half of the pediatricians in our sample reported that they never provide any advice on subjects as important as parent-child relationships, psychomotor stimulation and language. These results agreed with previous studies in the literature, which have shown that the pediatric agenda is primarily focused on biomedical issues (Galuska et al., 2002; Manning et al., 2009; Olson et al., 2004; Schuster et al., 2000; Young et al., 1998).

Although some pediatricians in our sample did not strictly follow some of the traditional paradigms of medical practice and adhered to the general principles of health promotion, their discourse still showed a strong predominance of biomedical features.

A change in the professional profile of pediatricians is needed to attain the goals of the Well-child program, and this change will only be possible when pediatricians have broader training, material support and high-quality technical scientific guidelines. In addition, initial and on-thejob training should place more emphasis on the communication techniques and social skills of pediatricians (Nelson, Wissow, \& Cheng, 2003; Nunes \& Ayala, 2010; Wissow et al., 2005).

\section{References}

American Academy of Pediatrics. (1993).The pediatrician and the "new morbidity". Policy statement. Pediatrics, 92, 731733.

Berkule-Silberman, S. B., Dreyer, B. R., Huberman, H. S., Klass, P. E., \& Mendelsohn, A. L. (2010). Sources of parenting information in Low SES Mothers. Clinical Pediatrics, 49, 560-568.

Brayden, R. M., \& Poole, S. R. (1995). Common behavioral problems in infants and children. Primary Care, 22, 81-97.

Cheng, T., DeWitt, T., Savageau, J., \& O’Connor, K. (1999). Determinants of counseling in primary care pediatric practice. Archives of Pediatrics \& Adolescent Medicine, 153, 629-635.

Cheng, T. L., Savageau, J. A., DeWitt, T. G., Bigelow, C., \& Charney, E. (1996a). Assessing mother's attitudes about the physician's role in child health promotion. American Journal of Public Health, 86, 1809-1812.

Cheng, T. L., Savageau, J. A., DeWitt, T. G., Bigelow, C., \& Charney, E. (1996b). Expectations, goals, and perceived effectiveness of child health supervision. Clinical Pediatrics (Philadelphia), 35, 129-137.

Crespo, M. (1999). Formación de especialistas en pediatría y en las subespecialidades pediátricas. Revista Pediatría de Atención Primaria, 1, 37-52.

Dirección General de Atención Primaria y Promoción de la Salud. (1990). Guía para la salud infantil. Sevilla, España: Junta de Andalucía e Consejería de Salud.

Galuska, D. A., Fulton, J. E., Powell, K., Burgeson, C. R., Pratt, M., Elster, A., et al. (2002) Pediatrician Counseling about preventive health topics: Results from the Physicians' Practices Survey, 1998-1999. Pediatrics, 109, E83.

Glascoe, F. (1997). Parents' concerns about children's development: Prescreening technique or screening test? Pediatrics, 99, 522-528.

Glascoe, F., \& Dworkin, P. H. (1995). The role of parents in the detection of developmental and behavioral problems. Pediatrics, 95, 829-836. 
Goodnow, J., \& Collins, A. (1994). Development according to parents. The nature, sources and consequences of parents' ideas. Hillsdale, NJ: Lawrence Erlbaum.

Harkness, S., Super, C. M., \& Keefer, C. (1992). Learning to be an American parent: How cultural models gain directive force. In R. G. Andrade \& C. Strauss (Eds.), Human motives and cultural models (pp. 163-178). Cambridge, MA: Cambridge University Press.

Harkness, S., Super, C. M., Keefer, C. H., Raghavan, C. S., \& Kipp, F. H. (1996). Ask the doctor: The negotiation of cultural models in American parent-pediatrician discourse. In S. Harkness \& C. M. Super (Eds.), Parents' cultural belief systems: Their origins, expressions and consequences (pp. 289-310). New York: Guilford.

Hart, C., Kelleher, K., Drotar, D., \& Scholle, S. (2007). Parentprovider communication and parental satisfaction with care of children with psychosocial problems. Patient Education and Counseling, 68, 179-185.

Hidalgo, M. V. (2003). Transición a la maternidad y la paternidad. In J. M. Rodrigo \& J. Palacios (Eds.), Familia y desarrollo humano (2. ed., pp. 161-180). Madrid, España: Alianza.

Hidalgo, M. V., \& Menéndez, S. (2009). Apoyo a las familias durante la transición a la maternidad y la paternidad. Familia: Revista de Ciencias y Orientación Familiar, 38, 133-152.

Hidalgo, M. V., Menéndez, S., López, I., \& Sánchez, J. (2004). Nacer a la vida: un programa de apoyo y formación durante la transición a la maternidad y la paternidad. Infancia y Aprendizaje, 27, 407-415.

Krippendorff, K. (1980). Content analysis. An introduction to its methodology. Newbury Park, CA: Sage.

Levetown, M., \& Committee on Bioethics. (2008). Communicating with children and families: From everyday interactions to skill in conveying distressing information. Pediatrics, 121, e1441-e1460.

Macphee, D. (1984). The pediatrician as source of information about child development. Journal of Pediatric Psychology, 9, 87-100.

Manning, K. M., Ariza, A. J., Massimino, T. K., \& Binns, H. J. (2009). Health supervision visits of very young children: Time addressing 3 key topics. Clinical Pediatrics, 48, 931-938.

Maroy, C. (1997). Análise qualitativa de entrevistas. In L. Albarello, F. Dignef, C. Maroy, D. Ruquoy, \& P. Saint-George (Eds.), Práticas e métodos de investigação em ciências sociais (pp. 117-155). Lisboa, Portugal: Gradiva.

McGillicuddy-DeLisi, A. V. (1992). Parents' beliefs and children's personal social development. In I. E. Sigel, A. V. McGillicuddy-DeLisi, \& J. J. Goodnow (Eds.), Parental belief systems ( $2^{\text {nd }}$ ed., pp. 115-142). Hillsdale, NJ: Lawrence Erlbaum.

Mesibov, G. B., Shroeder, C. S., \& Wesson, L. (1993). Parental concerns about their children. In H. C. Roberts (Ed.), Readings in pediatric psychology (pp. 307-316). New York: Plenum Press.

Monteiro, M. B., \& Castro, P. (Eds.). (1997). Cada cabeça sua sentença. Ideias dos adultos sobre as crianças. Oeiras, Portugal: Celta.

Nelson, C., Wissow, L., \& Cheng, T. (2003). Effectiveness of anticipatory guidance: Recent developments. Current Opinion in Pediatrics, 15(6), 630-635.

Nunes, C. (2004). Pediatras, madres y políticas de salud infantil. Unpublished doctoral dissertation, Universidad de Sevilla, Spain.
Nunes, C. (2008). Ideas de las madres sobre el desarrollo y educación de los niños. Revista INFAD. International Journal of Development and Educational Psychology, 1(4), 43-58.

Nunes, C., \& Ayala, A. (2007). ¿Qué piensan las madres sobre el programa de seguimiento de la salud infantil? Revista Pediatría de Atención Primaria, 9, 411-425.

Nunes, C., \& Ayala, A. (2010). Communication techniques used by pediatricians in the well-child program visits: A pilot study. Patient Education and Counseling, 78, 79-84.

Olson, L. M., Inkelas, M., Halfon, N., Schuster, M. A., O’Connor, K. G., \& Mistry, R. (2004). Overview of the content of health supervision for young children: Reports from parents and pediatricians. Pediatrics, 113, 1907-1916.

Palacios, J., Hidalgo, M. V., \& Moreno, M. C. (2003). Ideologías familiares sobre el desarrollo y la educación infantil. In M. J. Rodrigo \& J. Palacios (Eds.), Familia y desarrollo humano (pp. 181-199). Madrid, España: Alianza.

Schonwald, A., Horan, K., \& Huntington, N. (2009). Developmental screening: Is there enough time? Clinical Pediatrics, 48, 648-655.

Schuster, M. A., Duan, N., Regalado, M., \& Klein, D. J. (2000). Anticipatory guidance: What information do parents receive? What information do they want? Archives of Pediatrics \& Adolescent Medicine, 154, 1191-1198.

Siegel, I. E. (1992). The belief-behavior connection: A resolvable dilemma. In I. E. Sigel, A. V. McGillicuddyDeLisi, \& J. J. Goodnow (Eds.), Parental belief systems ( $2^{\text {nd }}$ ed., pp. 433-456). Hillsdale, NJ: Lawrence Erlbaum.

Wissow, L., Larson, S., Anderson, J., \& Hadjiisky, E. (2005). Pediatric residents' responses that discourage discussion of psychosocial problems in primary care. Pediatrics, 115 , 15691578.

Young, K., Davis, K., Schoen, C., \& Parker, S. (1998). Listening to parents: A national survey of parents with young children. Archives of Pediatrics \& Adolescent Medicine, 152, 255-262. 